\title{
Requirement of available phosphorus by female broiler chickens keeping the calcium:available phosphorus ratio at $2: 1$
}

\author{
Heloisa Helena de Carvalho Melloㄹ, Paulo Cezar Gomes ${ }^{1}$, Horacio Santiago Rostagno', \\ Luiz Fernando Teixeira Albino ${ }^{1}$, Rita Flávia Miranda de Oliveira', Tatiana Cristina da Rocha', \\ Cleverson Luís Nascimento Ribeiro ${ }^{1}$
}

\begin{abstract}
${ }^{1}$ Departamento de Zootecnia, Universidade Federal de Viçosa, Viçosa, MG, Brazil.
ABSTRACT - Four trials were conducted to determine the requirements of available phosphorus (aP) of female broiler chicks from 1 to 10 (exp.1), 11 to 21 (exp.2), 22 to 33 (exp.3), and from 34 to 46 (exp.4) days of age, keeping the calcium: available phosphorus ratio equal to $2: 1$. In each trial, $480 \mathrm{Cobb}$ broilers were randomly allotted in a completely randomized design with 6 treatments, 8 replicates and 10 birds per pen. The levels of aP ranged from 2.0 to $5.5 \mathrm{~g} / \mathrm{kg}$ (Exp. 1), 1.9 to $5.4 \mathrm{~g} / \mathrm{kg}$ (exp. 2), 1.8 to $5.3 \mathrm{~g} / \mathrm{kg}$ (exp. 3) and 1.7 to $5.2 \mathrm{~g} / \mathrm{kg}$ of diet (exp. 4), in increments of $0.7 \mathrm{~g} / \mathrm{kg}$. The experimental diets were formulated using corn and soybean meal and the available phosphorus was considered $33 \%$ of total phosphorus. The characteristics evaluated were body weight gain, feed intake, feed conversion ratio and bone parameters. For female broiler chicks from 1 to $10 ; 11$ to $21 ; 22$ to 33 ; and from 34 to 46 days of age, the levels of available phosphorus and calcium recommended are 4.59 and $9.18 ; 3.88$ and $7.76 ; 3.58$ and 7.16 ; and 2.56 and $5.12 \mathrm{~g} / \mathrm{kg}$ of diet, respectively.
\end{abstract}

Key Words: chicken, minerals, performance, ration, tibia

\section{Introduction}

Minerals exert important biological functions in the animal organism. Among the minerals, phosphorus is one of the most important for broilers because it is related to bone formation, the structure of nucleic acids, phospholipids, cell membranes, acid-base balance and energy transfer (Underwood \& Suttle, 1999). Both calcium and phosphorus co-exist in many biological functions; therefore, the dietary requirement of these minerals is interdependent (Rama Rao et al., 2006).

Most of the concern about the influence of calcium on phosphorus metabolism is focused on deleterious effects from calcium excess. This occurs because diets for broilers have been formulated with high levels of calcium, and recently, nutritionists have considered it a problem. Therefore, the efforts of nutritionists are to reduce the calcium levels of diets. However, both insufficient levels of calcium and inadequate calcium:avaliable phosphorus ratios might decrease broiler performance.

Researchers, aiming to access the phosphorus requirements for broilers, kept the calcium dietary constant in broiler diets. In these trials, some treatments may be affected because they contain calcium:available phosphorus ratio above or below the recommended. Schoulten et al. (2002) hypothesized that both higher and lower levels of calcium adversely affect the absorption of phosphorus. According to the authors, the reduction of phosphorus uptake when the calcium level is very low is due to the imbalance of calcium and phosphorus in the diet.

Studies aimedatdetermining thenutritional requirements of phosphorus have indicated that the requirement of chickens may be overestimated (Kheiri \& Rahmani, 2006; Rama Rao et al., 2006). It is possible that the calcium levels used in the experiments of phosphorus requirements are above those required by the animal, resulting in high levels of phosphorus requirements. Thus, to determine the requirement of available phosphorus, it is important to consider the same calcium:available phosphorus ratios in all experimental diets, avoiding erroneous conclusions.

Most of the experiments are conducted with male broilers. It is known that the sex of birds is one factor that influences their nutritional requirement. Therefore, further studies with broiler females should be conducted.

This experiment was conducted to determine the requirements for available phosphorus of females broilers at different ages, keeping the calcium:available phosphorus ratio at $2: 1$. 


\section{Material and Methods}

Four trials with identical design were conducted at Universidade Federal de Viçosa, using commercial female Cobb broilers.

Four hundred and eighty (480) commercial female broilers were used in each of the four experiments. Broilers were randomly allotted in a completely randomized design with 6 treatments, 8 replicates and 10 birds on floor pens.

The 1st experiment was conducted with broilers from 1 to 10 days of age, initial weight of $46.98 \pm 0.23 \mathrm{~g}$; the $2 \mathrm{nd}$ experiment, with broilers from 11 to 21 days of age, initial weight of $301.6 \pm 3.55 \mathrm{~g}$; the 3 rd experiment, with broilers from 22 to 33 days of age, initial weight of $842.0 \pm 7.35 \mathrm{~g}$; the 4th experiment, with broilers from 34 to 46 days of age, initial weight of $1.598 \pm 12.90 \mathrm{~g}$.

The experiments were conducted with different groups of broilers. All birds were acquired with one day of age and reared until the beginning of experiments. The animals were fed standard diets in floor pens prior the beginning of the each experiment, according to Rostagno et al. (2005).

Fluorescent lamps supplemented natural daylight to provide 24 hours light daily. Care and management of the animals followed the recommendations of the Cobb Management Guidelines.

The experimental diets were formulated to contain 6 levels of available phosphorus, maintaining the ratio between calcium ( $\mathrm{Ca}$ ) and available phosphorus (aP) identical for all diets (Table 1). The Ca:aP ratio used was $2: 1$, according to Rostagno et al. (2005).

Corn and soybean meal diets were formulated to meet broiler requirements (Rostagno et al., 2005) for all nutrients, except for $\mathrm{Ca}$ and aP (Table 2). Limestone and dicalcium phosphate were used to obtain the levels of dietary aP and $\mathrm{Ca}$ while maintaining a constant $\mathrm{Ca}: \mathrm{aP}$ ratio of $2: 1$. The levels of all nutrients except $\mathrm{aP}$ and $\mathrm{Ca}$ were formulated to be identical for all diets.

The available phosphorus was calculated as $33 \%$ of total phosphorus (Rostagno et al., 2005). Birds were given free access to feed and water.
During the experimental period of $1 \mathrm{st}, 2 \mathrm{nd}$, 3rd and 4th experiments, the minimum and maximum temperatures inside the broiler houses were 22 and $31^{\circ} \mathrm{C} ; 21$ and $29^{\circ} \mathrm{C}$; 19 and $29^{\circ} \mathrm{C} ; 20$ and $28^{\circ} \mathrm{C}$, respectively.

At the end of each experiment, all birds were weighed, feed intake was measured, and body weight gain and feed conversion ratio were calculated. Three birds per pen were sampled and then euthanized by cervical dislocation, and left tibias were collected for determinations of the percentage of bone ash, calcium and phosphorus in ash. The muscle tissue, along with cartilage caps, was removed, and all tibia were stored in a freezer until further analysis.

Table 2 - Composition $(\mathrm{g} / \mathrm{kg})$ of basal diets fed to commercial broilers chicks

\begin{tabular}{|c|c|c|c|c|}
\hline Ingredients & Exp.1 & Exp.2 & Exp.3 & Exp.4 \\
\hline Corn & 522.01 & 539.62 & 569.35 & 611.51 \\
\hline Soybean meal & 397.02 & 378.81 & 339.47 & 297.23 \\
\hline Oil soybean & 29.39 & 34.85 & 44.78 & 44.81 \\
\hline Sodium chloride & 5.15 & 4.93 & 4.71 & 4.43 \\
\hline Choline & 1.00 & 1.00 & 1.00 & 1.00 \\
\hline DL-methionine $99 \%$ & 3.38 & 2.20 & 2.13 & 2.04 \\
\hline L-lysine $\mathrm{HCl} 78 \%$ & 2.69 & 0.86 & 1.13 & 1.69 \\
\hline L-threonine $98 \%$ & 1.11 & 0.05 & 0.11 & 0.32 \\
\hline Antioxidant ${ }^{1}$ & 0.10 & 0.10 & 0.10 & 0.10 \\
\hline Vitamin premix ${ }^{2}$ & 1.00 & 1.00 & 1.00 & 1.00 \\
\hline Trace mineral premix ${ }^{3}$ & 0.50 & 0.50 & 0.50 & 0.50 \\
\hline Coccidiostat $^{4}$ & 0.50 & 0.50 & 0.50 & 0.50 \\
\hline Additive growth-promoter ${ }^{5}$ & 0.10 & 0.10 & 0.10 & 0 \\
\hline $\mathrm{Ca}$ and $\mathrm{P}$ sources and inert & 36.05 & 35.48 & 35.12 & 34.76 \\
\hline \multicolumn{5}{|l|}{ Calculated nutrient composition } \\
\hline Metabolizable energy (kcal/kg) & 2,950 & 3,000 & 3,100 & 3,150 \\
\hline Crude protein (g/kg) & 220.0 & 210.0 & 195.0 & 180.0 \\
\hline Sodium (g/kg) & 2.23 & 2.14 & 2.05 & 1. 94 \\
\hline Digestible lysine (g/kg) & 13.30 & 11.46 & 10.73 & 10.17 \\
\hline $\begin{array}{l}\text { Digestible methionine } \\
+ \text { cystine }(\mathrm{g} / \mathrm{kg})\end{array}$ & 9.44 & 8.14 & 7.73 & 7.32 \\
\hline Digestible threonine $(\mathrm{g} / \mathrm{kg})$ & 8.65 & 7.45 & 6.97 & 6.61 \\
\hline \multicolumn{5}{|c|}{$\begin{array}{l}{ }^{1} \text { Butylated hydroxytoluene. } \\
{ }^{2} \text { Vitamin premix provided: vit. A - 12,000,000 UI; vit. D3 - 2,200,000 UI; vit. E - } \\
30,000 \mathrm{UI} \text {; vit. B1 - 2,200 mg; vit B2 - 6,000 mg; vit. B6 - 3,300 mg; pantothenic } \\
\text { acid - } 13,000 \mathrm{mg} \text {; biotin - } 110 \mathrm{mg} \text {; vit. K3 - 2,500 mg; folic acid - 1,000 mg; } \\
\text { nicotinic acid -53,0000 mg; niacin - 25,000 mg; vit. B12 - 16,000 } \mu \text { g; selenium - } 0.25 \mathrm{~g} \text {; } \\
\text { antioxidant - } 120,000 \mathrm{mg} \text {. } \\
{ }^{3} \text { Trace mineral provided: manganese - } 75,000 \mathrm{mg} \text {; iron - 20,000 mg; zinc - } 50,000 \mathrm{mg} \text {; } \\
\text { copper - 4,000 mg; iodine } 1,500 \mathrm{mg} \text {. } \\
{ }^{4} \text { Salinomicin } 12 \% \text {. } \\
{ }^{5} \text { Avilamycin } 10 \% \text {. }\end{array}$} \\
\hline
\end{tabular}

Table 1 - Available phosphorus (aP) and calcium (Ca) levels used in treatments $(\mathrm{T})$ according to each experiment

\begin{tabular}{|c|c|c|c|c|c|c|c|}
\hline & & $\mathrm{T} 1$ & $\mathrm{~T} 2$ & T3 & $\mathrm{T} 4$ & $\mathrm{~T} 5$ & T6 \\
\hline \multirow[t]{2}{*}{ Experiment 1 (birds from 1 to 10 days of age) } & $\mathrm{Ca}(\mathrm{g} / \mathrm{kg})$ & 4.0 & 5.4 & 6.8 & 8.2 & 9.6 & 11.0 \\
\hline & $\mathrm{aP}(\mathrm{g} / \mathrm{kg})$ & 2.0 & 2.7 & 3.4 & 4.1 & 4.8 & 5.5 \\
\hline \multirow[t]{2}{*}{ Experiment 2 (birds from 11 to 21 days of age) } & $\mathrm{Ca}(\mathrm{g} / \mathrm{kg})$ & 3.8 & 5.2 & 6.6 & 8.0 & 9.4 & 10.8 \\
\hline & $\mathrm{aP}(\mathrm{g} / \mathrm{kg})$ & 1.9 & 2.6 & 3.3 & 4.0 & 4.7 & 5.4 \\
\hline \multirow[t]{2}{*}{ Experiment 3 (birds from 22 to 33 days of age) } & $\mathrm{Ca}(\mathrm{g} / \mathrm{kg})$ & 3.6 & 5.0 & 6.4 & 7.8 & 9.2 & 10.6 \\
\hline & $\mathrm{aP}(\mathrm{g} / \mathrm{kg})$ & 1.8 & 2.5 & 3.2 & 3.9 & 4.6 & 5.3 \\
\hline \multirow[t]{2}{*}{ Experiment 4 (birds from 34 to 46 days of age) } & $\mathrm{Ca}(\mathrm{g} / \mathrm{kg})$ & 3.4 & 4.8 & 6.2 & 7.6 & 9.0 & 10.4 \\
\hline & $\mathrm{aP}(\mathrm{g} / \mathrm{kg})$ & 1.7 & 2.4 & 3.1 & 3.8 & 4.5 & 5.2 \\
\hline
\end{tabular}


Ash percentage was determined on a defatted dry matter basis on individual bones (Silva \& Queiroz, 2002).

Data were subjected to ANOVA using the software SAEG (Statistical Analysis System, version 9.1). Pens served as the experimental unit. The requirements of aP were estimated using polynomial regression equations. Data were subjected to analysis of variance with degrees of freedom split into polynomials. Data were also adjusted by the Linear Response Plateau model (LRP). The model set to explain the data was that which showed the lowest sum of squared deviations (SQD) and highest correlation coefficient $\left(\mathrm{R}^{2}\right)$. Significance of difference was based on the probability of a type I error set at $\mathrm{P} \leq 0.05$. From the level of aP, the requirement of $\mathrm{Ca}$ was determined and $\mathrm{Ca}$ : aP was adopted as equal to $2: 1$.

\section{Results and Discussion}

Body weight gain, feed conversion ratio, tibia ash, calcium and phosphorus in tibia ash of female broiler chickens of 1-10 days of age were significantly affected by the levels of aP in the diet $(\mathrm{P}<0.05)$ (Table 3$)$. Dietary aP levels did not affect feed intake $(\mathrm{P}>0.05)$. According to the LRP model, weight gain increased until reaching a plateau level at $3.27 \mathrm{~g} / \mathrm{kg}$ aP and feed conversion ratio decreased to the level of $4.59 \mathrm{~g} / \mathrm{kg}$ aP. Tibia ash increased to the levels of $4.38 \mathrm{~g} / \mathrm{kg}$ aP. Calcium in tibia ash was maximized by $4.58 \mathrm{~g} / \mathrm{kg}$ aP. Phosphorus in tibia ash increased linearly according to the aP levels in the diet (Table 4).

Weight gain, feed conversion ratio and feed intake of female broiler chickens of 11-21 days of age were not affected by levels of aP (Table 5). The aP levels studied influenced the tibia ash quadratically. However, according to the Linear Response Plateau (LRP) model, which showed higher $\mathrm{R}^{2}$, the maximum tibia ash was obtained at the level of 3.88 of aP in the diet. Calcium and phosphorus in tibia ash were maximized by 4.46 and $4.22 \mathrm{~g} / \mathrm{kg}$ aP, respectively (Table 6).

The body weight and feed intake of broilers were unaffected by dietary aP of commercial female broilers of 22-33 days of age (Table 7). The levels of aP studied influenced the feed conversion ratio, which decreased to the level $3.07 \mathrm{~g} / \mathrm{kg}$. The tibia ash increased up to a plateau with aP at $4.97 \mathrm{~g} / \mathrm{kg}$ in the diet. Calcium in tibia ash increased

Table 3 - Effects of available phosphorus levels on performance and bone parameters of commercial female broilers of 1-10 days of age

\begin{tabular}{|c|c|c|c|c|c|c|c|c|c|c|}
\hline & \multicolumn{6}{|c|}{ Available phosphorus (g/kg) } & \multirow{2}{*}{ CV $(\%)$} & \multicolumn{3}{|c|}{ Regression analysis } \\
\hline & 2.0 & 2.7 & 3.4 & 4.1 & 4.8 & 5.5 & & Linear & Quadratic & LRP \\
\hline Body weight gain (g) & 206.22 & 208.58 & 207.70 & 220.54 & 220.43 & 211.93 & 4.18 & 0.500 & 0.082 & 0.021 \\
\hline Feed intake $(\mathrm{g})$ & 288.44 & 292.14 & 288.10 & 292.79 & 290.70 & 281.10 & 3.70 & 0.255 & 0.096 & 0.259 \\
\hline Tibia ash $\left(\mathrm{g} \mathrm{kg}^{-1}\right)$ & 414.4 & 450.7 & 479.6 & 492.8 & 501.4 & 518.0 & 2.11 & 0.001 & 0.001 & 0.004 \\
\hline $\mathrm{Ca}$ in the tibia $\left(\mathrm{g} \mathrm{kg}^{-1}\right)$ & 142.8 & 157.0 & 165.5 & 165.5 & 173.2 & 175.9 & 2.89 & 0.003 & 0.057 & 0.038 \\
\hline $\mathrm{P}$ in the tibia $\left(\mathrm{g} \mathrm{kg}^{-1}\right)$ & 81.7 & 87.8 & 94.3 & 95.2 & 98.2 & 103.4 & 3.57 & 0.007 & 0.160 & 0.004 \\
\hline
\end{tabular}

CV - coefficient of variation; LRP - linear response plateau.

Table 4 - Requirement of available phosphorus and calcium for female broiler chickens of 1-10 days of age

\begin{tabular}{|c|c|c|c|c|c|c|}
\hline & Model & Equation & $\begin{array}{c}\text { Plateau/Max/min. } \\
\text { Point }\end{array}$ & $\begin{array}{c}\text { Ca:aP requirement } \\
(\mathrm{g} / \mathrm{kg})\end{array}$ & SQD & $\mathrm{R} 2$ \\
\hline \multirow[t]{2}{*}{ Body weight gain } & Quadratic & $\hat{\mathrm{Y}}=177.22+171.32 \mathrm{X}-186.57 \mathrm{X} 2$ & $\hat{\mathrm{Y}}=216.55$ & $9.18: 4.59$ & 89.83 & 0.56 \\
\hline & LRP & $\hat{\mathrm{Y}}=193.08+57.66 \mathrm{X}$ & $\hat{\mathrm{Y}}=211.92$ & $6.54: 3.27$ & 42.12 & 0.79 \\
\hline Feed conversion Ratio & LRP & $\hat{\mathrm{Y}}=1.4795-0.330 \mathrm{X}$ & $\hat{\mathrm{Y}}=1.328$ & $9.18: 4.59$ & 0.0010 & 0.83 \\
\hline Tibia ash & LRP & $\hat{\mathrm{Y}}=34.42+37.73 \mathrm{X}$ & $\hat{\mathrm{Y}}=50.96$ & $8.76: 4.38$ & 2.70 & 0.96 \\
\hline $\mathrm{Ca}$ in the tibia & LRP & $\hat{\mathrm{Y}}=12.43+10.95 \mathrm{X}$ & $\hat{\mathrm{Y}}=17.45$ & $9.16: 4.58$ & 0.540 & 0.85 \\
\hline $\mathrm{P}$ in the tibia & Linear & $\hat{\mathrm{Y}}=7.19+5.73 \mathrm{X}$ & & $\geq 11.0: 5.50$ & 0.128 & 0.95 \\
\hline
\end{tabular}

SQD - sum of squared deviations; LRP - linear response plateau.

Table 5 - Effects of levels of available phosphorus on performance and bone parameters of commercial female broilers of 11-21 days of age

\begin{tabular}{|c|c|c|c|c|c|c|c|c|c|c|}
\hline & \multicolumn{6}{|c|}{ Available phosphorus (g/kg) } & \multirow{2}{*}{$\mathrm{CV}(\%)$} & \multicolumn{3}{|c|}{ Regression analysis } \\
\hline & 1.9 & 2.6 & 3.3 & 4.0 & 4.7 & 5.4 & & Linear & Quadratic & LRP \\
\hline Body weight gain (g) & 450.32 & 448.24 & 444.06 & 448.79 & 430.00 & 431.75 & 5.01 & 0.350 & 0.587 & 0.121 \\
\hline Feed intake (g) & 703.06 & 701.31 & 698.73 & 696.94 & 687.56 & 677.44 & 3.59 & 0.250 & 0.396 & 0.070 \\
\hline Feed conversion ratio & 1.566 & 1.570 & 1.575 & 1.553 & 1.600 & 1.569 & 4.22 & 0.674 & 0.975 & 0.269 \\
\hline Tibia ash $\left(\mathrm{g} \mathrm{kg}^{-1}\right)$ & 495.3 & 509.1 & 525.8 & 536.1 & 535.7 & 541.8 & 1.37 & 0.001 & 0.004 & 0.017 \\
\hline $\mathrm{Ca}$ in the tibia $\left(\mathrm{g} \mathrm{kg}^{-1}\right)$ & 170.3 & 175.8 & 186.6 & 184.9 & 187.3 & 195.1 & 3.28 & 0.000 & 0.431 & 0.041 \\
\hline$P$ in the tibia $\left(\mathrm{g} \mathrm{kg}^{-1}\right)$ & 87.0 & 86.4 & 88.5 & 98.9 & 91.3 & 93.4 & 3.47 & 0.001 & 0.898 & 0.062 \\
\hline
\end{tabular}

$\mathrm{CV}$ - coefficient of variation; LRP - linear response plateau. 
with $2.95 \mathrm{~g} / \mathrm{kg}$ of aP. Phosphorus in tibia ash increased up to a plateau with $3.54 \mathrm{~g} / \mathrm{kg}$ of aP in the diet (Table 8).

Performance and bone mineralization of female broilers from 34 to 46 days of age was unaffected by dietary aP (Table 9), indicating that the lower levels studied were sufficient to ensure the performance of birds $(1.7 \mathrm{~g} / \mathrm{kg}$ of aP).

There was great variation of aP requirement by broilers from 1 to 10 days of age in accordance with the parameters under study. For weight gain, the aP level required by the chickens was lower than for the feed conversion ratio $(3.27 \times 4.59 \mathrm{~g} / \mathrm{kg})$. Rostagno et al. (2011) suggest for broiler females of 1-7 days of age, $4.70 \mathrm{~g} / \mathrm{kg}$ of aP. Although the level of aP recommended to improve weight gain is lower than the recommended in the literature (NRC, 1994;
Rostagno et al., 2011), this fact is in agreement with Yan et al. (2005), who concluded that broilers fed diet moderately deficient in phosphorus and calcium $(3.0 \mathrm{~g} / \mathrm{kg}$ aP and $6.0 \mathrm{~g} / \mathrm{kg} \mathrm{Ca}$ ) from birth to 18 days of age demonstrated the ability of partial adaptation to the deficiency, which was shown by the increased ileal absorption of phosphorus and calcium, the increased ileal phosphorus disappearance, compensatory growth and compensatory improvement in bone parameters.

There was no effect of dietary aP levels on feed intake for any of the periods studied. These results agree with Yan et al. (2005), who also observed no differences in feed intake when varying levels of calcium and phosphorus, but keeping the Ca:aP ratio at 2:1. This result is similar to data from Bunzen et al. (2007), who fed female broilers

Table 6 - Requirement of available phosphorus and calcium for female broiler chickens of 11-21 days of age

\begin{tabular}{|c|c|c|c|c|c|c|}
\hline & Model & Equation & $\begin{array}{c}\text { Plateau/Max/min. } \\
\text { Point }\end{array}$ & $\begin{array}{c}\text { Ca:aP requirement } \\
(\mathrm{g} / \mathrm{kg})\end{array}$ & SQD & $\mathrm{R} 2$ \\
\hline \multirow[t]{2}{*}{ Tibia ash } & Quadratic & $\hat{\mathrm{Y}}=42.94+41.67 \mathrm{X}-39.03 \mathrm{X} 2$ & $\hat{Y}=54.06$ & $10.68: 5.34$ & 0.26 & 0.98 \\
\hline & LRP & $\hat{Y}=45.33+21.79 X$ & $\hat{Y}=53.78$ & $7.76: 3.88$ & 0.24 & 0.99 \\
\hline $\mathrm{Ca}$ in the tibia & LRP & $\hat{\mathrm{Y}}=15.62+7.83 \mathrm{X}$ & $\hat{\mathrm{Y}}=0.1912$ & $8.92: 4.46$ & 0.58 & 0.84 \\
\hline $\mathrm{P}$ in the tibia & LRP & $\hat{Y}=8.03+2.84 X$ & $\hat{\mathrm{Y}}=9.23$ & $8.44: 4.22$ & 0.0817 & 0.76 \\
\hline
\end{tabular}

SQD - sum of squared deviations; LRP - linear response plateau.

Table 7 - Effects of levels of available phosphorus on performance and bone parameters of commercial female broilers of 22-33 days of age

\begin{tabular}{|c|c|c|c|c|c|c|c|c|c|c|}
\hline & \multicolumn{6}{|c|}{ Available phosphorus (g/kg) } & \multirow{2}{*}{ CV $(\%)$} & \multicolumn{3}{|c|}{ Regression analysis } \\
\hline & 1.8 & 2.5 & 3.2 & 3.9 & 4.6 & 5.3 & & Linear & Quadratic & LRP \\
\hline Body weight gain (g) & 753.41 & 764.41 & 761.20 & 768.42 & 760.59 & 755.64 & 2.23 & 0.913 & 0.077 & 0.075 \\
\hline Feed intake (g) & 1.298 & 1.296 & 1.298 & 1.313 & 1.312 & 1.316 & 2.29 & 0.080 & 0.883 & 0.066 \\
\hline Feed conversion ratio & 1.721 & 1.696 & 1.704 & 1.710 & 1.726 & 1.743 & 1.48 & 0.008 & 0.005 & 0.350 \\
\hline Tibia ash $\left(\mathrm{g} \mathrm{kg}^{-1}\right)$ & 488.8 & 498.5 & 504.3 & 513.6 & 523.1 & 526.9 & 1.37 & 0.000 & 0.639 & 0.001 \\
\hline $\mathrm{Ca}$ in the tibia $\left(\mathrm{g} \mathrm{kg}^{-1}\right)$ & 167.0 & 170.7 & 178.5 & 172.9 & 180.2 & 174.0 & 2.39 & 0.003 & 0.014 & 0.001 \\
\hline $\mathrm{P}$ in the tibia $\left(\mathrm{g} \mathrm{kg}^{-1}\right)$ & 84.6 & 86.9 & 85.7 & 91.1 & 87.3 & 90.5 & 2.63 & 0.046 & 0.618 & 0.047 \\
\hline
\end{tabular}

$\mathrm{CV}$ - coefficient of variation; LRP - linear response plateau.

Table 8 - Requirement of available phosphorus and calcium for male broiler chickens of 22-33 days of age

\begin{tabular}{|c|c|c|c|c|c|c|}
\hline & Model & Equation & $\begin{array}{c}\text { Plateau/Max/min. } \\
\text { Point }\end{array}$ & $\begin{array}{c}\text { Ca:aP requirement } \\
(\mathrm{g} / \mathrm{kg})\end{array}$ & SQD & $\mathrm{R} 2$ \\
\hline Feed conversion ratio & Quadratic & $\hat{\mathrm{Y}}=1.78-0.547 \mathrm{X}+0.890 \mathrm{X} 2$ & $\hat{Y}=1.696$ & $6.14: 3.07$ & 0.00013 & 0.90 \\
\hline Tibia ash & LRP & $\hat{\mathrm{Y}}=46.63+11.98 \mathrm{X}$ & $\hat{\mathrm{Y}}=52.68$ & 9.94:4.97 & 0.0410 & 0.99 \\
\hline $\mathrm{Ca}$ in the tibia & LRP & $\hat{\mathrm{Y}}=15.15+8.20 \mathrm{X}$ & $\hat{\mathrm{Y}}=17.57$ & $5.90: 2.95$ & 0.0264 & 0.96 \\
\hline \multirow[t]{2}{*}{$P$ in the tibia } & Linear & $\hat{Y}=8.24+1.46 X$ & & $\geq 10.6: 5.3$ & 0.184 & 0.54 \\
\hline & LRP & $\hat{Y}=7.97+2.57 X$ & $\hat{\mathrm{Y}}=8.89$ & $7.14: 3.57$ & 0.0774 & 0.67 \\
\hline
\end{tabular}

SQD - sum of squared deviations; LRP - linear response plateau.

Table 9 - Effects of levels of available phosphorus on performance and bone parameters of commercial female broilers of $34-46$ days of age

\begin{tabular}{|c|c|c|c|c|c|c|c|c|c|}
\hline & \multicolumn{6}{|c|}{ Available phosphorus (g/kg) } & \multirow{2}{*}{$\mathrm{CV}(\%)$} & \multicolumn{2}{|c|}{ Regression analysis } \\
\hline & 1.7 & 2.4 & 3.1 & 3.8 & 4.5 & 5.2 & & Linear & Quadratic \\
\hline Body weight gain $(\mathrm{g})$ & 707.3 & 716.93 & 691.48 & 714.63 & 720.27 & 722.36 & 4.50 & 0.259 & 0.410 \\
\hline Feed intake $(\mathrm{g})$ & 1.728 & 1.730 & 1.701 & 1.724 & 1.749 & 1.725 & 4.03 & 0.700 & 0.748 \\
\hline Feed conversion ratio & 2.443 & 2.416 & 2.458 & 2.414 & 2.433 & 2.393 & 3.11 & 0.283 & 0.524 \\
\hline Tibia ash $\left(\mathrm{g} \mathrm{kg}^{-1}\right)$ & 513.8 & 525.4 & 527.8 & 526.9 & 527.4 & 528.5 & 1.63 & 0.186 & 0.142 \\
\hline $\mathrm{Ca}$ in the tibia $\left(\mathrm{g} \mathrm{kg}^{-1}\right)$ & 176.0 & 176.2 & 170.8 & 179.1 & 174.6 & 183.1 & 2.05 & 0.190 & 0.140 \\
\hline$P$ in the tibia $\left(\mathrm{g} \mathrm{kg}^{-1}\right)$ & 83.1 & 89.4 & 87.8 & 84.1 & 86.8 & 90.5 & 2.51 & 0.110 & 0.295 \\
\hline
\end{tabular}

$\mathrm{CV}$ - coefficient of variation. 
dietary levels of $\mathrm{Ca}$ and $\mathrm{aP}$, keeping the $\mathrm{Ca}: \mathrm{aP}$ at 2:1, and verified no differences in feed intake. Similarly, Venalainen et al. (2006) also verified no differences in the feed intake of broiler males and females from 1 to 36 days of age fed levels of aP, keeping the Ca:aP ratio at 2:1.

Several authors have reported significant effect of phosphorus levels on feed intake (Runho et al., 2001; Viveros et al., 2002; Queiroz et al., 2008), but these authors used several Ca:aP ratios different from 2:1, which may have caused the response obtained. Theses authors observed that the highest ratios resulted in lower feed intake. When Ca:aP ratios other than 2:1 are used, there can be an oversupply of these minerals, followed by a deficiency of another. These effects were studied by Bar et al. (2003), who reported that dietary $\mathrm{Ca}$ restriction caused slight hypocalcaemia and dietary $\mathrm{P}$ restriction caused hypercalcaemia and hypophosphataemia. According to Lobaugh et al. (1981), the calcium appetite may be inhibited by increased concentrations of ionic calcium in the blood and the change in behavior is sufficiently rapid to play a role in the calcium homeostasis of birds. The diets used in current experiment maintained the $\mathrm{Ca}: \mathrm{aP}$ ratio at $2: 1$, so it can be inferred that there was no hypercalcemia or hypocalcemia due to the imbalance of this relationship, which may have contributed for the feed intake not to change according to treatments.

For female broilers from 1 to 10 days of age, the requirement of aP to improve performance and bone parameters were, respectively, $4.59 \mathrm{~g} / \mathrm{kg}$ and $4.38 \mathrm{~g} / \mathrm{kg}$, corresponding to $\mathrm{Ca}$ at 9.18 and $8.76 \mathrm{~g} / \mathrm{kg}$. It was found that similar levels of aP were required to improve performance and bone parameters at this stage of production. However, this result contradicts the propositions of various authors, in which higher requirement of aP is necessary to improve bone mineralization than performance (Brugalli et al., 1999; Waldroup et al., 2000; Queiroz et al., 2008). However, these results agree with Bar et al. (2003), who concluded that $\mathrm{P}$ requirements for growth and bone ash are similar for 1 to 22-day-old chicks and Persia \& Saylor (2006), who estimated similar aP requirement for weight gain, feed intake and tibia ash for broilers of 8-22 days of age.

Body weight gain, feed intake and feed conversion ratio of females broilers from 11 to 21 days of age were not influenced by dietary levels of aP $(\mathrm{P}>0.05)$, indicating that the lowest levels studied $(1.9 \mathrm{~g} / \mathrm{kg})$ was sufficient to ensure bird performance. This level is lower than the level recommended by Rostagno et al. (2011), of $3.91 \mathrm{~g} / \mathrm{kg}$ for female chickens from 8 to 21 days of age. Although the tendency of declining levels of phosphorus was demonstrated in recent studies, there are no reports of results similar to our study $(1.9 \mathrm{~g} / \mathrm{kg})$. It is important to consider that the chicks were fed from 1 to 10 days of age with normal levels of calcium and phosphorus. Therefore, a hypothesis is that from 11 to 21 days of age there is no time for chicks to develop a deficiency of these minerals in the organism.

Although no mortality was verified in the lowest level studied (aP at $1.9 \mathrm{~g} / \mathrm{kg}$ of diet), a large reduction in phosphorus levels in diets should only be done with previous studies on its effect on the incidence of broken bones in the processing line. According to Driver et al. (2005), decreasing the amount of calcium in the broiler diet may improve performance and increase profitability; however, this should not be at the expense of increased leg problems.

For female broiler chickens from 11 to 21 days of age, the aP requirement ranged from 1.90 to $4.22 \mathrm{~g} / \mathrm{kg}$ of diet, corresponding to $\mathrm{Ca}$ at 3.80 and $8.44 \mathrm{~g} / \mathrm{kg}$. Waldroup (1999) suggested that in relative terms, the amount of $P$ needed to maximize bone calcification is higher than the amount to maximize performance and mortality. In fact, it was found that smaller amounts of aP were required to improve weight gain and feed conversion ratio rather than improve bone parameters, and there was no mortality at the lowest level studied.

Reducing the dietary levels of calcium and phosphorus up to an amount that ensures the weight gain and feed conversion ratio of the birds does not necessarily result in increased mortality or the occurrence of leg problems. Further studies about the influence of dietary phosphorus and calcium on the percentage of fractures in the processing line are needed to obtain practical data to enable the reduction of these minerals in the diet. According Rath et al. (2000), it should be evident that not only bone minerals, but also the bone organic matrix factors, are responsible for bone strength.

Feed conversion ratio of female broilers from 22 to 33 days was influenced by the dietary levels of aP. The quadratic effects observed for the feed conversion ratio of broilers from 22 to 33 days of age confirm those by Bunzen et al. (2007), who also observed a quadratic effect of levels of phosphorus on performance of broiler chickens from 22 to 35 days of age. These authors recommended using aP at $3.41 \mathrm{~g} / \mathrm{kg}$ in the diet of broiler chickens. The contents of tibia ash, calcium in the tibia and phosphorus in the tibia were maximized with aP at 4.97, 2.95 and $3.54 \mathrm{~g} / \mathrm{kg}$, respectively. Venalainen et al. (2006) also observed that the content of tibia ash, calcium and phosphorus in the tibia increased by curvilinear effect, according to dietary phosphorus levels. However, the authors observed that the dietary concentration of aP had no effect on the breaking strength of the tibia. 
For female broilers from 22 to 33 days of age, the requirement of aPranged from 3.07 to $4.97 \mathrm{~g} / \mathrm{kg}$, respectively, to improve performance and to maximize the tibia ash content. Thus, aP at $3.07 \mathrm{~g} / \mathrm{kg}$ was the value recommended, whereas feed conversion ratio was maximized and there were no leg problems at this level.

The tibia ash content, which is influenced by dietary levels of aP, has been a variable used as an indicator of bone quality in many studies. According Yan et al. (2005), it is important to feed broiler chickens phosphorus concentrations that minimize carcass downgrades and carcass losses in the processing plants due to bone breakage or bone weakness; however, it is not clear whether maximum bone ash is required for minimum processing plant downgrades.

Body weight gain, feed intake and feed conversion rate of female broilers from 34 to 46 days of age were not influenced by dietary levels of aP, indicating that the lowest level studied $(1.7 \mathrm{~g} / \mathrm{kg})$ was sufficient to ensure the bird performance. This result is lower than the recommended $(2.98 \mathrm{~g} / \mathrm{kg}$ ) by Rostagno et al. (2011) for female broilers from 34 to 42 days of age. The tendency of decreasing dietary levels of aP has been observed mainly in the finish phases of production. Some researchers observed lower requirement of aP in the finishing phases. Dhandu \& Angel (2003) found a aP requirement of $2.0 \mathrm{~g} / \mathrm{kg}$ for female broilers from 22 to 42 days of age based on tibia ash weight. Corroborating these authors, Waldroup (1999) suggests that during the later stages of production, when a significant amount of feed is consumed, there is little if any need for supplemental $\mathrm{P}$ in a typical corn-soybean meal broiler diet.

The reduction of aP requirement in the finishing stages of production of birds can be explained by lower bone mineralization in that stage. As birds got older, the demand for aP was reduced due to a reduction of ash percentage in the bone. This fact agrees with Barreiro et al. (2009), who reported that ash, calcium and phosphorus in the bone of broilers reach their maximum at 22 days of age. In addition, the older birds are capable of using organic phosphorus more efficiently.

Tibia ash, phosphorus and calcium in the tibia of female broilers from 34 to 46 days of age were not influenced by the levels of aP in the diet.

With great concern about the potential for phosphorus pollution from the excreta of birds, it has become important not to provide this mineral in excess in diets. According to Yan et al. (2005) when we consider that breed, nutrition and management can all affect growth rate and, therefore, the phosphorus and calcium requirements of birds, it becomes an extremely difficult issue to formulate poultry diets to maximize bone ash and, at the same time, avoid excessive phosphorus excretion, which increases rapidly once bone ash is maximized.

Considering the performance parameters, the lowest studied level (aP at $1.7 \mathrm{~g} / \mathrm{kg}$ of diet) was sufficient to ensure the performance of broilers. However, to maintain the bone quality, the aP requirement of broiler females from 34 to 46 days was $2.56 \mathrm{~g} / \mathrm{kg}$. The bone parameter used to determine the requirement of aP was the tibia ash, considering the importance of this variable, as reported by Driver et al. (2006), who found a negative correlation between percentage of tibia ash and the amount of tibias and femurs broken during processing.

Low levels of aP were required by broilers using a $\mathrm{Ca}$ aP ratio equal to $2: 1$; if the dietary $\mathrm{Ca}$ is not in excess, the aP requirement may be reduced. In fact, Rama Rao et al. (2006) reported that the tibia ash content was at its maximum when the ratio between the $\mathrm{Ca}$ and nonphytin phosphorus was maintained at 2:1 in the diet, irrespective of the levels of these minerals in the diet.

According to the results of present experiment, it was possible to observe that the tibia ash was maximum at 2233 days of age; therefore, studies on the requirement of minerals for broilers older than 22 days should be conducted criteriously, because the variations in tibia ash in this phase might be due to the bird physiology and not to treatments. The bone ash and mineral percentage increased at 22 day of age, due to the higher mineral requirement at this age (Barreiro et al., 2009). Talaty et al. (2009) reported that the bone mineral density of commercial male and female broilers reached its peak at 4 week of age.

In summary, birds need larger amount of aP in the initial phase of production when large amounts of these minerals are required for bone mineralization. It was found that at all periods of production, the use of $\mathrm{Ca}$ :aP ratio at 2:1 led to reduction of levels of dietary phosphorus, without affecting the performance and mortality of birds. This experiment did not consider utilization of phytase in the diets. Since phytase increases availability of phosphorus, the nutritionists who use broiler diets with phytase should verify the possibility of higher reduction of dietary calcium and available phosphorus than found in this experiment.

\section{Conclusions}

For female broiler chicks from 1 to $10 ; 11$ to $21 ; 22$ to 33 ; and 34 to 46 days of age, the levels of available phosphorus and calcium recommended are 4.59 and 9.18 ; 3.88 and $7.76 ; 3.07$ and 6.14 ; and 2.56 and $5.12 \mathrm{~g} / \mathrm{kg}$, respectively, corresponding to the consumption of aP and 
$\mathrm{Ca}$ in weight gain of 6.27 and $12.55 ; 6.09$ and $12.12 ; 5.26$ and 10.52 ; and 6.21 and $12.42 \mathrm{mg} / \mathrm{g}$.

\section{References}

BAR, A.; SHINDER, D.; YOSEFI, S. et al. Metabolism and requirements for calcium and phosphorus in the fast-growing chicken as affected by age. British Journal of Nutrition, v.89. p.51-60, 2003.

BARREIRO, F.R.; SAGULA, A.L.; JUNQUEIRA, O.M. et al. Densitometric and biochemical values of broiler tibias at different ages. Poultry Science, v.88, p.2644-2648, 2009.

BRUGALLI, I.; SILVA, D.J.; ALBINO, L.F.T. et al. Exigência de fósforo disponível e efeito da granulometria na biodisponibilidade de fósforo da farinha de carne e ossos para pintos de corte. Revista Brasileira de Zootecnia, v.28, n.6, p.1288-1296, 1999.

BUNZEN, S.; ROSTAGNO, H.S.; ALBINO, L.F.T. et al. Calcium and available phosphorus levels at 2:1 ratio for growing broiler chickens. In: POULTRY SCIENCE JOINT MEETING, 2007, Atlanta. Anais... Atlanta: International Poultry Scientific Forum Georgia World Congress Center, 2007. p.73

DHANDU, A.S.; ANGEL, R. Broiler nonphytin phosphorus requirement in the finisher and withdrawal phases of a commercial four-phase feeding system. Poultry Science, v.82, p.1257-1265, 2003.

DRIVER, J.P.; PESTI, G.M.; BAKALLI, R.M. et al. Calcium requirements of the modern broiler chicken as influenced by dietary protein and age. Poultry Science, v.84, p.1629-1639, 2005.

DRIVER, J.P.; PESTI, G.M.; BAKALLI, R.I. et al. The effect of feeding calcium- and phosphorus-deficient diets to broiler chickens during the starting and growing-finishing phases on carcass quality. Poultry Science, v.85, p.1939-1946, 2006.

KHEIRI, F.; RAHMANI, H.R. The effect of reducing calcium and phosphorous on broiler performance. International Journal of Poultry Science, v.5, n. 1, p.22-25, 2006.

LOBAUGH, B.; JOSHUA, I.G.; MUELLER, W.J. Regulation of calcium appetite in broiler chickens. The Journal of Nutrition, v.111, p.298-306, 1981.

NATIONAL RESEARCH COUNCIL - NRC. Nutrient requirements of poultry. 9. rev. ed. Washington, D.C.: Subcommittee on Poultry Nutrition. National Research Council, 1994. 176p.

PERSIA, M.E.; SAYLOR, W.W. Effects of broiler strain. dietary nonphytate phosphorus and phytase supplementation on chick performance and tibia ash. Journal Applied Poultry Research, v. 15, p.72-81, 2006

QUEIROZ, L.S.; BERTECHINI, A.G.; RODRIGUES, P.B. et al. Utilização de fosfatos comerciais para frangos de corte na fase inicial. Pesquisa Agropecuária Brasileira, v.43, p.1421-1427, 2008.
RAMA RAO, S.V.; RAJU, M.V.L.N.; REDDY, M.R. et al. Interaction between dietary calcium and non-phytate phosphorus levels on growth. bone mineralization and mineral excretion in commercial broilers. Animal Feed Science and Technology, v.131, p.133-148, 2006.

RATH, N.C.; RUFF, G.R.; RUFF, W.E. et al. Factors regulating bone maturity and strength in poultry. Poultry Science, v.79, p.1024-1032, 2000.

ROSTAGNO, H.S.; ALBINO, L.F.T.; DONZELE, J.L. et al. Tabelas brasileiras para aves e suínos: composição de alimentos e exigências nutricionais. 2.ed. Viçosa, MG: UFV, Departamento de Zootecnia, 2005. 186p.

ROSTAGNO, H.S.; ALBINO, L.F.T.; DONZELE, J.L. et al. Tabelas brasileiras para aves e suínos: composição de alimentos e exigências nutricionais. 3.ed. Viçosa, MG: UFV, Departamento de Zootecnia, 2011. 252p.

RUNHO, R.C.; GOMES, P.C.; ROSTAGNO, H.S. et al. Exigência de fósforo disponível para frangos de corte machos e fêmeas de 1 a 21 dias de idade. Revista Brasileira de Zootecnia, v.30, p.187-196, 2001.

SCHOULTEN, N.A.; TEIXEIRA, A.S.; BERTECHINI, A.G. et al. Efeito dos níveis de cálcio sobre a absorção de minerais em dietas iniciais para frangos de corte suplementadas com fitase. Ciência e Agrotecnologia, v.26, n.6. p.1313-1321, 2002.

SILVA. D.J.; QUEIROZ, A.C. Análise de alimentos (métodos químicos e biológicos). 3.ed. Viçosa, MG: UFV, Imprensa Universitária, 2002. 235p.

TALATY, P.N.; KATANBAF, M.N.; HESTER, P.Y. Life cycle changes in bone mineralization and bone size traits of commercial broilers. Poultry Science, v.88, p.1070-1077, 2009.

UNDERWOOD. E.J.; SUTTLE. N.F. The mineral nutrition of livestock. 3.ed. New York: CAB International. 1999. 614p.

VENALAINEN, E.; VALAJA, J.; JALAVA, T. Effects of dietary metabolisable energy. calcium and phosphorus on bone mineralisation leg weakness and performance of broiler chickens. British Poultry Science, v.47, p.301-310, 2006.

VIVEROS, A.; BRENES, A.; ARIJA, I. et al. Effects of microbial phytase supplementation on mineral utilization and serum enzyme activities in broiler chicks fed different levels of phosphorus. Poultry Science, v.81, p.1172-1183, 2002.

WALDROUP, P.W. Nutritional approaches to reducing phosphorus excretion by poultry. Poultry Science, v.78, p.683-691, 1999.

WALDROUP, P.W.; KERSEY, J.H.; SALEH, E.A. et al. Nonphytate phosphorus requirement and phosphorus excretion of broiler chicks fed diets composed of normal or high available phosphate corn with and without microbial phytase. Poultry Science, v.79, p. 1451-1459, 2000.

YAN, F.; ANGEL, R.; ASHWELL, C. et al. Evaluation of the broiler's ability to adaPt to an early moderate deficiency of phosphorus and calcium. Poultry Science, v.84, p.1232-1241, 2005. 